\title{
Imperfect Role in Speech Tactics of Will Expression Effect
}

\author{
Evgenia Penzeva \\ Irkutsk National Research Technical University, Institute of Linguistics and Intercultural Communication, 664074, Irkutsk, \\ Russia
}

\begin{abstract}
This paper presents the results of studies of the imperfect in the speech tactics of will expression effect (request, persuasion, advice and suggestion). The pragmatic peculiarities of this grammar form were determined. The influence of the speech tactics on imperfect semantics, the influence of the imperfect on the speech tactics and the interaction of the general speech strategy with the speech tactics containing imperfect, used in it, were examined. It is established that in the speech tactics of will expression effect, the imperfect has a different quantity of meanings in various tactics and marginal significations (the irreal imperfect, the imperfect of curtesy, the imperfect of intention) are used more often than prototypical ones. It means the Expositive (colloquial speech) tends to deal with later acquired meanings. Due to the imperfect, the speech tactics of the will expression strategy gets a special flexibility, softness and even carefulness in communication with other people. The socializing becomes more formal and trustful. Thus, the imperfect can be used for recognizing the speaker's speech goals and even determining his strategy line.
\end{abstract}

\section{Introduction}

Studies of the grammatical form of the imperfect and the problem of interpreting its semantics attracted and continue attracting the attention of both foreign and domestic linguists (see the works of N.M. Firsova [1], A. Bello [2] and others). The Imperfect is a time-tested form that is difficult to analyze due to the variety of its uses. Various theories were developed that sought to determine the single meaning of this form. There is no doubt that all previous studies of this grammatical form have a linguistic value, which must be taken into account in further scientific research.

In modern scientific concepts, there is a transition from linguistic immanent to its setting to consider the language in itself and for itself to anthropological linguistics, suggesting the study of language in close connection with the man, his consciousness, thinking, spiritual and practical activity.

Anthropocentric direction in contemporary linguistics is also associated with a discursive approach (see the works of T.A. van Dijk [3], H.H. Clark, E.F. Schaefer [4], Krapivkina [5] and others), one of the manifestations of which is the tactical use of the grammatical form, taking into consideration the intentions and communicative goals of the speaker. Being a concept of pragmatics, speech tactics is closely connected with speech influence and speech behavior.

Language, representing an objective phenomenon, existing as some system that has developed historically, acting according to certain internal laws, at the same time realizes the main purpose - to serve the purposes of communication. Putting thoughts into a language form, a person pursues basically three goals: to inform the interlocutor (listener) about this or that fact of reality; to express the attitude to this information, that is to give it an estimate; to exert a certain influence on a person who perceives his speech.

The function of the effect of the discourse on the addressee is realized by various linguistic means. A special role in achieving the perlocutive effect, of course, belongs to the verb, which has long been considered the center of the sentence, its dynamic basis, the engine of the strategic line of discourse. A verb is a language category that is ideally adapted by a language system to perform speech impact functions in any type of discourse.

In connection with the human factor in linguistics, the addressee's active participation influences the use of the imperfect in the utterance. His discourse is a form of action, since to speak means to influence the other (and oneself), his/her conceptual system. From this position, the imperfect should be viewed not only as a linguistic means of expression of tense and aspect, but also as a means of expressing the communicative intention of the speaker as a substance reflecting the connection between the speaker and the hearer.

Modern linguistic studies pay attention to the study of the whole complex of facts (conditions) handling the communicative process and determining the process of realizing one or another utterance. Speech strategies and tactics are given a great importance in recent times (see the works of O.S. Issers [6], T.E. Yanko [7] C. Hardy, I. Palmer, N. Phillips [8] and others).

* Corresponding author: evpenzeva@ yandex.ru 
The identification of the strategic use of the imperfect in the dialogue makes it possible to identify speech tactics in which an interested participant in a communicative act could use the imperfect to influence the interlocutor effectively. Identification of the discursive aspects of the imperfect in modern Spanish is conducted from the position of a strategic approach to discourse, based on the types of tactical techniques corresponding to utterances with the use of the considered grammatical form.

The traditional division of semiotics into three main disciplines - semantics, syntactics and pragmatics - made in his time by C.S. Pierce and then taken by C. Maurice [9], was accepted as a theoretical basis by modern linguistics. Until now, scientific literature has mainly explored the semantics of the imperfect and the syntactics, where the imperfect was studied in distribution with other times. As for pragmatics, at the present time the first works, devoted to the discursive use of the Spanish language, began to appear in modern Spanish linguistic literature (see the works of A. Bello [2], M.L. Gutiérrez Araus [10]), but they are of general nature. Thus, the imperfect is still little understood from the standpoint of pragmatics, and the strategic purpose of this form has not yet been considered.

\section{Results}

To date, it is generally accepted that language is a person's activity directed toward a specific goal, to the best expression of one's thoughts and feelings. At the heart of any discourse, there is a communicative strategy, formed by a specific situation and those tasks that the speaker sets himself. So the choice and interpretation of the reference situation, the communicative content of the utterance are determined by the addressee, his model of the world. In this connection, the subject of speech is recognized as the central pragmatic category, and a strategy and tactics are the main concept in the works of many linguists who study speech activity. The notion of the speaker of the world, i.e. his picture of the world, is reflected primarily at the lexical level, but the choice of grammatical forms also represents the creative vision of the extralinguistic situation by the addressee. A.V. Kravchenko formulates in general terms the question that is at the center of attention of modern pragmatics: "What influences the choice of precisely this and not another linguistic form in every concrete case of verbal communication, and why does this form have exactly that meaning which it in this case has?" [11]. A strategic approach to discourse makes it possible to determine the reasons for the author of the utterance to use that particular grammatical form in a given situation, i.e. to determine the situational-strategic motivation for the use of the grammatical form, in particular, the imperfect.

The functioning of the linguistic sign, including the grammatical form, in speech is not limited only to a representative function, which consists in the transfer of subject-logical information about the external world. The linguistic sign has a symptomatic function, thanks to which the senders of the signs express their feelings, emotions, moods, and a signal function that creates the opportunity to induce recipients of signs to a certain behavior, actions, actions, infect them with certain feelings, etc.

The concept of the strategic use of linguistic units in speech presupposes the inclusion in the mechanism of creating a speaker of the idea of the cognitive activity of the hearer. Pragmalinguistics, studying the relationship of signs to interpreters, considers discourse as a means of expressing the intent of the addressee to convey a message to the addressee and to exert a certain influence on him/her.

To determine the pragmatic features of the imperfect as a tactical tool used to build a strategy for expression of will, it is necessary to find out:

1) the influence of tactics on the value of the imperfect;

2) the influence of the imperfect on tactics;

3) the interaction of the overall strategy and the speech tactics implemented in it.

The materials for the study were dialogues from the works of contemporary Spanish and Latin American authors.

The main research methods are induction method, elements of transformation analysis, comparative analysis, contextual analysis, an interpretative method, a method of continuous sampling and a method of questioning (examples have been verified through the involvement of the informants - native speakers).

The will has the greatest impact on the interlocutor: it is aimed at his "behavior and actions, forcing him to act in accordance with the will and desire of the speaker" [12]. In other words, the will of the addressee is inextricably linked with the prompting of the addressee to a particular action. In this regard, it seems necessary to mention the most well-known wording of the success conditions relating to motivation. Thus, R. Conrad singles out six conditions for success:

1) the speaker $(S)$ wants the listener $(L)$ to perform the action (p) - "the conditions of sincerity";

2) $S$ has a purpose / intention to induce L to commit p;

3 ) the moment of time (t) of committing $p$ by L later than the moment $t$ of pronouncing $p$;

4) L is obliged to make p / L is not obliged to make p;

5) L can make p;

6) $\mathrm{L}$ is ready to make $\mathrm{p}$ [13].

In this strategy, we can distinguish the following tactics, in which the imperfect is most frequently used: the tactics of the request, persuasion, advice, proposal, tactics of requesting information. Let us consider some of them in more detail.

The tactic of the request is a polite motivation for the addressee to act in favor of the speaker. Since the addressee is not obliged to perform the action, about which he is asked, the speaker seeks to construct his statement in such a way that it affects the interlocutor as much as possible. Specificity of the dialogue: the limited time for consideration, the unplanned nature of the request, the obvious spontaneity of motivation in the form of a request, promotes the use of habitual, persistent modes of expression in speech [14]. As the material shows, the imperfect used in motivation can 
refer to such means, in particular, in the situation of the request. In the tactics under consideration, the imperfect designates the present action and, as a consequence, the perlocutive effect of this action is directed to the future (in spite of the fact that the prototypical meaning of this form is past time). This is what attracts the attention of the listener. In this situation, the grammatical form under consideration gives an explicitly polite tone to the request (a formal request between close friends or relatives can be expressed both in grammatical forms of the imperative and in the present tense of the indicative mood). In traditional Spanish grammar, this imperfect is called the Imperfecto of Politeness (imperfecto de cortesía o de modestia) (see the works of S. Gili y Gaya [15], G. Reyes [16] and others). Politeness is usually understood as behavior that aims at preventing and eliminating conflicts (see G.N. Leech [17] and others). The use of the imperfect in the request is tactical, since it avoids conflicts, does not violate the harmony in the relationship with the communication partner, mitigates potential aggression, without offending dignity and without infringing the rights of the communication partner. Thus, the emphasis is on the listener, on which the achievement or failure to reach the target depends [18]. Let us consider an example:

(1) F-Federico; $Y$-Yoni.

Federico se acercó a Yoni.

F-Oye tú, ¿va a haber baile luego, y eso?

$Y$-Supongo. Aquí cada uno hace lo que quiere...

$F$ - Digo por si van a venir más chicas. Chicas de aquí.

$Y$ - Sí, creo que se lo han dicho a Isabel y a Toñuca, y a las catalanas, ¿por qué?

$F$ - Por si podía yo avisar a una amiga mía.

$Y$ - ¿A Julia Ruiz?- preguntó Yoni.

$F-S i$, ¿no te importa?

$Y$-Por mí trae a quien quieras... [19].

This example is interesting because it contains a vivid example of the tactics of the request, the "link", which is an imperfect (podía). In this example, protagonist Federico has a setup - to have a good time, a motive - he likes the girl, the goal is he wants to invite her to the party, but since the party is "a guest-night" (that is, only friends and good acquaintances of the host's owner), Federico is not sure in that he will be allowed to bring the girl. In accordance with these parameters, he builds his strategic line of conduct, in which he uses various tactics to achieve his goal. The main among these tactics expressing the "global goal" of the addressee is the tactic of the request containing the imperfect. The considered grammatical form (the imperfect of modesty) expresses the action of the future, which attracts the attention of the addressee and allows the addressee to use simultaneously the tactical methods of self-presentation of the "game of lowering oneself / games to increase the partner", creating the effect of "underlined politeness." With the help of additional tactics of requesting information, the speaker prepares the addressee for the actual request, so this example is quite long. Thus, the tactics of the request, the "dynamic basis" of which is the imperfect, marks the entire strategic line of the addressee. Since the attitude of the participants in the communication coincide, Federico gets permission to bring the girl; he achieves the desired result. The abovementioned example reveals an "indirect lining" [20], since the listener does not care about the physical or mental ability of a young person to invite a girl to a party, but is referring to a request for permission to bring her. The request is pragmatically more neutral than the threat or order, since it leaves the addressee with the option of choice (consent / refusal), assumes the nonstrict binding of the perlocutive effect and is characterized by less interference of the addressee speaking in the personal sphere [21]. There are situations in which the realization of a request using the imperfect is performed without the naming of a direct speech target, it is "the so-called implication, which in linguistic theories has been accepted to be understood ... as "implication" [20]. "Implication" is often used in the dialogue to manipulate the interlocutor. Let us consider an example:

(2) G-Goyita; L-Luis.

Luis Colina la había reconocido y se acercó por detrás a saludarlas. A Julia no se acordaba si la conocía o no.

G-Julia Ruiz-presentó Goyita-. Ya nos íbamos a casa. Está desagradable. - Se cruzó la rebeca, sin decidirse a echar a andar. Julia miraba hacia los jardincillos del centro en actitud expectante.

L-Bueno, si no os importa, os acompaño. Sale uno a lo tontuno, ya a estas horas, y gusta encontrarse con las chicas guapas [19].

In this example, the girl aims to encourage the young man to accompany them with a girlfriend to the house. She chooses (basic, cooperative) speech tactics of the indirect request (hint) and realizes it in the message of intention to leave (the form of the imperfect in such situations is called the Spanish Imperfecto de conato, or the imperfection of intention and denotes the proximity of the action, and also emphasizes its incompleteness). The addressee performs the operations that underlie his manipulations, this is a correction of the addressee's model of the world, namely, the creation and introduction into the listener's consciousness of common elements and presuppositions "it's too late, the girls need to be carried out" and the operation with the basic categories "normality - anomaly" "Norm" - "escort as a guard". At the same time, in order to realize the tactical goal in the best possible way, the girl also uses auxiliary tactics: dialogical (control over the initiative) and selfpresentation tactics (playing the role of "we weak, defenseless" and increasing the role of the addressee "you are strong, you are the defender, you must accompany us, so that no one will offend us "), and nonverbal means (silence-expectation after expressing the intention to leave). Since "the assumption of the connectedness of the dialogue makes the listener look for the implicature, and the found implication is then a means of ensuring the coherence of the dialogue" [22], tactical reception was interpreted correctly as a request, as seen from the recipient's response (si no os importa, os acompaño); the aim of the addressee was achieved. The imperfect (íbamos) in this statement is a linguistic indicator that marks the whole strategy of will expression, since it solves the main strategic task in 
"motivating" a person to action (to fulfill this request). Thus, from the point of view of the pragmatic impact of the sign on human behavior, the imperfect can be used to recognize the intentions of the addressee to serve as an indicator by which we can judge tactical tasks and, in some situations, the strategic intent of the addressee. The purpose of these tactics coincides with the strategic goal of the leader's will; therefore they can be attributed to the main ones, in which the imperfect is the "driving force". Informants who were involved in confirming or refuting the analysis attributed these statements and similar ones to the implementation of the tactics of the request. The informant's values of the imperfect, acquired by this tense in the implementation of these tactics, coincide with the data we have revealed: in the tactic of the request, the surreal imperfect, the imperfect of modesty and the imperfection of intention are actualized.

The imperfect can be used in discourse in order to implement the tactics of the council. According to the addressee, the person to whom advice is given is in a difficult situation.

The adviser expresses a positive attitude towards someone who needs advice, while the addressee avoids categorical judgments, emphasizes his subjective, personal point of view, and communicates with his partner as if on an equal footing, deliberately ignoring the status difference [23]. That is why the imperfect is a language tool that is "ideally" suitable for use in the tactics under consideration. Let us consider an example:

(3) $G$-García (el poicía), L-Lucía.

Me hicieron esperar en una salita miserable durante casi una hora. Al fin entró un tipo a hablar conmigo.

Se llamaba García.. Tenía aspecto de estar aburridisimo.

G - Yo que Ud me quedaba tranquila durante algunos días, seguro que al final regresará. Estas cosas pasan muу а menudo...

L - ¡Estupendo! ¡Así trabaja la policía de este país! ¡Por

supuesto que es mucho más cómodo pensar que

Ramón me ha dejado que ponerse a buscarlo! barboté, furiosa.

$G$-Mire. Sí que le buscamos. Hemos seguido la rutina

habitual. Todos los hospitales, todos los centros de primeros auxilios ... [24].

In example (3), an imperfect (quedaba) is used in a discourse that implements the council tactics included in the general strategy of will expression. This (referential) situation concerns the disappearance of the husband (the predicament) of a young woman who comes to the police station to find out how the investigation is progressing. A policeman who does not want to do this business and who believes that Lucia's husband ran away from her, advises her not to worry, wait a few days, because her husband will certainly make her known. The goal of tactics is to suggest a way out of the situation that has arisen, to reassure the addressee. The motive for this tactic was the desire to dissuade the addressee from visiting the police station the next few days, so as not to bother them with their questions. Since the settings of the participants in the communication do not coincide, Lucia's reaction to the council is negative ( Asi trabaja la policía de este país! ¡Por supuesto que es mucho más cómodo pensar que Ramón me ha dejado que ponerse a buscarlo!). In this case, first of all, the participants' attitude of communication plays the role. The addressee can take advice, refuse it or even resent it, if this advice does not correspond to his idea of the best way out of the predicament. Imperfect in such terms is the most effective language tool for expressing advice and avoiding conflict. The imperfect in this tactic is used in the colloquial expression (Yo que Ud / tú ... me quedaba), which is the equivalent of the conditional period. According to G. Reyes, in a colloquial speech, the conditional period can be expressed in other ways: "en ocasiones la condicionalidad viene marcada en el habla coloquial por otras fórmulas más o menos complejas" [16].

The converted example demonstrates that the quedaba is used in this tactic instead of Potencial Simple and, by relating the action to the future, acquires the value of unreality (surreal imperfect), as the policeman, advising, draws the hypothetical, supposed situation to the addressee. Imperfect makes this tactic more flexible, presenting information in a special delicate way. This is primarily due to the fact that the advice "is not an attempt to force you to do something in the sense in which this can be said about the request. The advice reminds you of what will be best for you" [25]. This situation is confirmed by the following example:

(4) A-amiga; E-Elvira.

A - Te debías pintar un poco estos días, Elvira. Estás muy pálida. ... es que lo negro come tanto. Tienes mala cara...

E-Que más da. Yo estoy bien... si tuviera ganas de pintarme, me pintaria [19].

In this example, the imperfect (debías) is used for the tactics of advice, which implements an appeal to the mind. The purpose of the tactics used by one of the girls (A) is to motivate her friend for certain actions (pintar un poco). According to the girl, Elvira looks badly. The imperfect in the situations in question refers to the effect on the plan for the near future, representing a transposed verbal form (a surreal imperfect), which makes this utterance trustful. The analyzed examples show that the imperfect is used mainly to express advice that was not requested by the addressee (the addressee believes that the situation of the interlocutor leaves much to be desired and decides to help him without his consent), and since the advice sounds quite trustful, in most cases it remains either without attention, or causes an ironic remark. In advice tactics, the imperfect is usually used either in the colloquial form of the conditional period (Yo que tú / Ud ...) (in the apodozis) or using the verb deber (debía). In both cases, the imperfect has the unreal value.

The advice, expressed by the forms of the imperative, sounds quite obtrusive: unconcerned and trustful will be advice built using the grammatical form of the imperfect.

The importance of the imperfect, acquired by this form in such statements, is hypothetical, directed toward the future. 


\section{Conclusions}

Thus, the analysis of the use of the imperfect for the purpose of implementing the strategy of will expression has shown that in the tactics of the request the imperfect can be used in the discourse in its marginal values, such as the surreal imperfect, the imperfection of modesty (politeness), the imperfection of intention.

In the tactics of the advice, only the marginal value is realized - a surreal imperfect. The purpose of the tactics considered is to induce the interlocutor to certain actions or states.

The use of the imperfect in statements that implement selected tactics allows communicants to implement such pragmatic techniques as increasing the role of the addressee / decreasing the role of the addressee, emotionally tuning; control over the topic and others.

Thanks to the imperfect, the tactics included in the strategy of will expression acquires special flexibility, trust, softness and even caution in handling the interlocutor, communication acquires a more formal, confidential character.

The analyzed material demonstrates that the number of values in different tactics varies, while the marginal values exceed the prototypical ones in terms of frequency; therefore, the Expository (colloquial speech) tends to the newer acquired values.

The study of the imperfect from a discursive analysis of strategies and tactics allows a fresh look at this problem and reveals the pragmasemantic aspect in the use of the imperfect by participants in modern Spanish communication.

\section{References}

1. N.M. Firsova, Grammer stylistics of the modern Spanish language (Vysshaya shkola, Moscow, 1984)

2. A. Bello, Gramática de la lengua castellana (Editorial de ciencias sociales, La Habana, 1978)

3. T.A.van Dijk, Society and discourse: How social contexts influence text and talk (Pompeu Fabra University, Barcelona, 2009)

4. H.H. Clark, E.F. Schaefer, Cognitive science 13, 259-294 (1989)

5. O.A. Krapivkina, Middle-East Journal of Scientific Research 20, 833-843 (2014)

6. O.C. Issers, Communicative strategies and tactics of the Russian speech (Editorial URSS, Moscow, 2003)

7. T.E. Yanko, Cognitive strategies of discourse. Twenty years after, Siberian Philological Journal 2, 172-182 (2015)

8. C. Hardy, I. Palmer, N. Phillips, Human Relations 53, 1227-1248 (2000)

9. Ch. Moris, Semiotika: collection of scientific papers (Akademichesky proekt, Moscow, 2001)

10. M.L. Gutiérrez Araus, Revista española de Linguística 2, 275-300 (1998)
11. A.V. Kravchenko, Issues of the designative theory: Self-absorption. Deictically. Indexicality (Irkutsk Un-ty, Irkutsk, 1992)

12. L.L. Fyodorova, Linguistic issues 6, 46-50 (1991)

13. R. Conrad, New in foreign linguistics 16, 349-384 (1985)

14. G. M. Yarmarkina, Genres of speech: a collection of scientific articles 3, 262-268 (2002)

15. S. Gili y Gaya, Curso superior de sintaxis española (Ins-to cubano del libro, La Habana, 1968)

16. G. Reyes, Cuaderno de gramática española (Arcolibros, S. L., Madrid, 1994)

17. G.N. Leech, Principles of Pragmatics (Longman, London, New York, 1983)

18. I.V. Zaikova, E.P. Penzeva, Vestnik IRNITU 7, 259263 (2013)

19. C.M. Gaite, Entre visillos (Ediciones Destino Ancora y Delfín, Barcelona, 1988).

20. E.V. Klyuev, Rhetoric: Invention. Disposition. Элокуци (Prior, Moscow, 1999)

21. I.N. Borisova, Indirect communication in speech systematics, Direct and indirect communication: science articles collection, 60-71 (2003)

22. E.V. Paducheva, IAN SLYA 4, 305-313 (1982)

23. V.Y. Karasiк, Language krug: personality, concepts, discourse (Gnosis, Moscow, 2004)

24. R. Montero, La hija del Caníbal (Espasa calpe, S. A., Madrid, 1999)

25. J. Searle, Mind, language and society. Philosophy in the real world (Basic Books, New York 1999) 